\title{
Process Development of Gluten-Free Snack Utilising Finger Millets
}

\author{
Jagbir Rehal $^{1}$, Poonam Aggarwal ${ }^{1}$ and Inderpreet Dhaliwal ${ }^{2}$ \\ ${ }^{1}$ Department of Food Science and Technology, \\ ${ }^{2}$ Departmentof Plant Breeding and Genetics, PAU, Ludhiana, India \\ *Corresponding author
}

\section{A B S T R A C T}

Keywords

Finger millet,

Potato flour,

Gluten-free, Fried

snack, Sensory

evaluation

Article Info

Accepted:

10 January 2021

Available Online:

10 February 2021
Snack industry is growing at an unprecedented rate and the consumers demand healthy and nutritious snacks for indulgence and satiation. Likewise, gluten free snacks are the need of the hour and to fill this gap a ready to cook gluten free snack was developed from finger millets by its supplementation in the form of roasted flour or cooked paste with $0,25,50$, 75 and 100 per cent supplementation in potato flour and the process for the snack preparation was standardized. Sensory evaluation of the snacks shows that the product with the addition of finger millet paste has very good overall acceptability scores as compared to that of finger millet roasted flour. The nutritional profile of the best treatment (P2) shows that the product, besides being energy dense is excellent source of nutrients and will cater to the need of both gluten sensitive and other population.

\section{Introduction}

Snacks are an important source of energy and nutrients and help us to sail through the long hours between the major meals of the day. Snack foods have no defined definition but usually known as smaller amounts of food eaten between the main meals (Chaplin and Smith, 2011; Vintro, 2015). Snacking has its importance in weight management, to stabilize blood sugar, provide satiation and in many other health benefits(Glassman, 2017). But healthy snacking is important otherwise it might lead to obesity and related health problems (Malik et al., 2013). The perception of snacks and convenience foods is changing, earlier they were perceived as non-healthy but now they are looked upon as a source of nutritional package to meet the dietary needs (Nakano and Washizu, 2020).

There is a spurt in the working women in the last couple of decades leading to increased incomes, nuclear families, emphasis on leisure time and less cooking time hence leading to a successive spurt in the market of convenience 
foods as well (Sehgal et al., 2010; Srinivasan and Shende, 2015). According to (Parameswaran, 2019) the revenue in the snack food segment amounts to over \$5,000 million in 2019 and the market is expected to grow annually by $7.5 \%$ (CAGR 2019-2023). There has been an explosive growth in this sector which amounts to almost six times the amount a decade ago (Jha, 2014). The consumer acceptance of the snacks depends on its organoleptic properties (Rehal et al., 2017). Consumers seek a range of products that deliver balanced nutrition in convenient formats. The diverse taste palette of the modern consumers provides great opportunity to integrate traditional flavours into new products so that consumers can indulge in guilt-free snacking. Consumers are now embracing whole grains, ancient food practices and healthy alternatives in a snack food. The market for traditional snacks for the people suffering from gluten intolerance (celiac disease) is very limited specially in the vegetarian segment. The products, if available do not provide adequate nutrition quality (Segundo et al., 2020). Extensive research has been conducted to enhance the nutritional profile of the gluten-free foods by employing nutrient-dense materials. Finger millet (Eleusine coracana) is a small millet is commonly consumed in India and accounts for $85 \%$ of the production in India(Gupta and Gupta, 2012).The major finger millet growing states in India are Karnataka, Tamil Nadu, Andhra Pradesh, Orissa, Maharashtra, Uttar Pradesh, and Gujarat (Sendhilvel and Veeramani, 2020).It is a store house of several potential health promoting components (Chetan, 2007) and is reported of having highest calcium among all cereals, high dietary fibre and polyphenols (Kumar et al., 2016). Due to its excellent nutritional profile and gluten-free nature the present study was considered with the objective to develop a process for the ready-o-cook gluten-free snack utilising finger millet.

\section{Materials and Methods}

Finger millet was procured from the department of Plant Breeding and Genetics, Punjab Agricultural University, Ludhiana for the year 2019.The grains were cleaned of twigs and stones, washed, dried in a tray dryer at $60^{\circ} \mathrm{C}$ for 24 hours. They were milled in a laboratory mill (Perten instruments) to get finger millet flour which was sieved, packed in polythene bags and stored in a refrigerator till further use. Potato flour (PF) were purchased from Iscon Balaji foods private limited. Fresh ginger, garlic, coriander, onion, green chillies along with salt, spices and soyabean oil were purchased from the local market. The finger millet flour was dry roasted in an open pan with continuous stirring till a toasty aroma emanates and the colour of the floor darkens a little. It was cooled and used as finger millet roasted flour (FMR). Further another batch of finger millet flour was cooked by mixing four times water and continuous stirring to obtain a paste. It was cooled and used as finger millet paste (FMP) (Fig. 1).

\section{Product preparation}

The PF and FMP was mixed in different levels as 100:0 (P0-control), 75:25 (P1), 50:50 (P2), 25:75 (P3), 0:100 (P4). Similarly, PF and FMR were mixed in the same levels to get R0, $\mathrm{R} 1, \mathrm{R} 2, \mathrm{R} 3$ and $\mathrm{R} 4$. It is pertinent to mention that P0 and R0 are treated as control. A $100 \mathrm{~g}$ mixture was prepared (finely chopped onion $30 \%$, ginger $15 \%$, garlic $10 \%$, chili $10 \%$, coriander $15 \%$, salt $15 \%$ and garam masala spice mix 5\%) and $5 \mathrm{~g} / 100 \mathrm{~g}$ of it was added in each formulation (Fig. 1). Required amount of water was added to each to get a pliable mass which was formed into balls of about 10 $\mathrm{g}$, pressed into patty shape and flash fried in refined soyabean oil at $200^{\circ} \mathrm{C}$ for 15 seconds. The product was cooled and packed in polyethylene zip lock bags and kept in deep 
freezer at $-20^{\circ} \mathrm{C}$. The frozen product was taken out from the freezer as and when required, deep fried in refined soybean oil at $180^{\circ} \mathrm{C}$ till a golden-brown colour was achieved. A total of 10 pieces were added in $500 \mathrm{ml}$ of hot oil at a time.

\section{Physico-chemical analysis}

The nutrient composition of gluten free snacks like dry matter, protein, fat, dietary fibre, ash content were estimated by following the standard procedures (AOAC 2005). The carbohydrate content was obtained by difference method (Yadav et al., 2012). Each analysis was done in triplicate. The best gluten free snack was also evaluated for its nutritional profile.

\section{Mineral estimation}

one gram of sample was digested in a combination of nitric acid and perchloric acid (3:1) made up to a volume of $50 \mathrm{ml}$ by deionized water. The minerals present in it were estimated by plasma atomic emission spectrometry (Thermo Scientific) (Kaur et al., 2018)

\section{Antioxidant activity}

To determine the total antioxidant activity of the aqueous extract DPPH (2,2-diphenyl-1picrylhydrazyl) radical scavenging activity was measured by using the method given by(Herrera-Balandrano et al., 2019). The radical scavenging activity was calculated by the formula given in equation 1 :

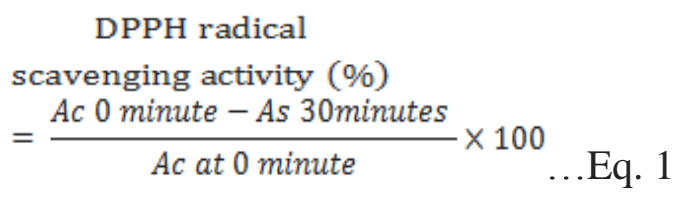

Where, Ac is absorbance of control; As is absorbance of sample

\section{Total phenolic content (TPC)}

The total phenolic content (TPC) was determined by extracting the phenolic compounds with $50 \mathrm{ml}$ of $80 \% \mathrm{v} / \mathrm{v}$ aqueous ethanol for 3 hours by refluxing at $40^{\circ} \mathrm{C}$.

The content of total phenolic compounds in this extract was then determined using the Folin Ciocalteu's colorimetric method where the absorbance was read at $765 \mathrm{~nm}$ after 30 minutes and results were expressed as gallic acid equivalents (mg GAE/100 g) (TapiaSalazar et al., 2019).

\section{Sensory evaluation}

The gluten-free snack was evaluated for their different sensory attributes viz. appearance, texture flavour, taste and overall acceptability on a 9-point hedonic scale (9-like extremely to 1-dislike extremely) by a panel of ten semitrained members in the age group of 24 to 58 years.

The product was served warm along with water for intermediate rinsing of mouth. Further the index of acceptability (IA\%) was calculated by the equation 2(Fernandes and Salas-Mellado, 2017)

\section{$I A(\%)=$ score $* 100 / 9 \ldots$ Eq. 2}

\section{Statistical analysis}

The data was expressed as mean \pm SD (ten replicates for sensory analysis, three for others). The results were then subject to ANOVA followed by Duncan multiple comparison test with $\mathrm{P} \leq 0.05$ significance level on SPSS 18.0 statistical software.

\section{Results and Discussion}

The proximate composition of the major raw materials is tabulated under table 1 . It reveals 
that the finger millet flour has more protein, fat, fibre and ash content then potato flour whereas potato flour has higher dry matter and carbohydrate content. Similar trend was seen for TPC and antioxidant activity of the raw material. Phenolic compounds can contribute considerably to the overall antioxidant capacity.

The ability of a compound to scavenge DPPH radical is dependent on their ability to pair with the unpaired electron of a radical.

Potato flakes or flour are the usually used material for the preparation of such fried snacks and its nutritive value is less and the addition of finger millet to the formulation will enhance the nutritive value of the product (Kanchana et al., 2018).

The sensory analysis of the developed snack product by the semi trained panel is revealed in table 2. It shows that among the two treatments, the product prepared by adding the finger millet paste obtained better scores for sensorial parameters than that which were prepared by using the roasted finger millet flour. This was evident from the high index of acceptability obtained by the treatment P0 to P3.

The dominating presence of finger millet paste in P4 had a deleterious effect on the sensorial properties and resulted in average overall acceptability. For samples containing roasted finger millets ( $\mathrm{R} 0$ to $\mathrm{R} 4$ ), the increasing percentage of finger millet resulted in a friable dough (R4) which was difficult to shape and fry leading to decreased scores in acceptability and texture and eventually less overall acceptability scores.

Among these R1 had the best index of acceptability and R0 sample (which does not contain any form of finger millet) and highest acceptability as the consumers are used to having snacks made with potato. The addition of finger millet in any form resulted in a decrease in the appearance scores probably due to the darkening of the crust due to the inherent dark colour of finger millet flour. The increase in the darkening results from maillard's reaction products during frying (Raleng et al., 2019).

The table 3 enlists the nutritional profile of the snack (P2). It is observed that the gluten-free potato-based snacks available in the market have a low amount of fibre but the incorporation of finger milletspaste results inadequate amount of fibre in the product.

There is considerable epidemiological evidence to support the physiological benefits of fibre intake like lower risk of CVD, diabetes, obesity and gastrointestinal disorders (IDA, 2018).

The supplementation with finger millet al., so results in higher antioxidant capacity apparently due to the polyphenols present in the flour. Similar observations were made by (Kumar et al., 2014).

The snack also has good amounts of minerals specially calcium (151.33 $\mathrm{mg} / 100 \mathrm{~g})$ and potassium $(355.01 \mathrm{mg} / 100 \mathrm{~g})$. The presence of positive calcium mineral content is necessary for maintaining healthy bones (Pettifor, 2004) and potassium helps in preventing the onset of diabetes, renal and cardiovascular diseases(He and MacGregor, 2008).

The developed snack has high energy content $(276.46 \mathrm{kcal} / 100 \mathrm{~g})$ and hence will provide good satiation level and at the same time deliver adequate nutrition to the consumers.

There is huge demand of convenience foods in the market specially gluten-free products which can provide adequate nutrition along with good taste and acceptability. 
Fig.1 Flow diagram for the preparation of ready-to-cook snack

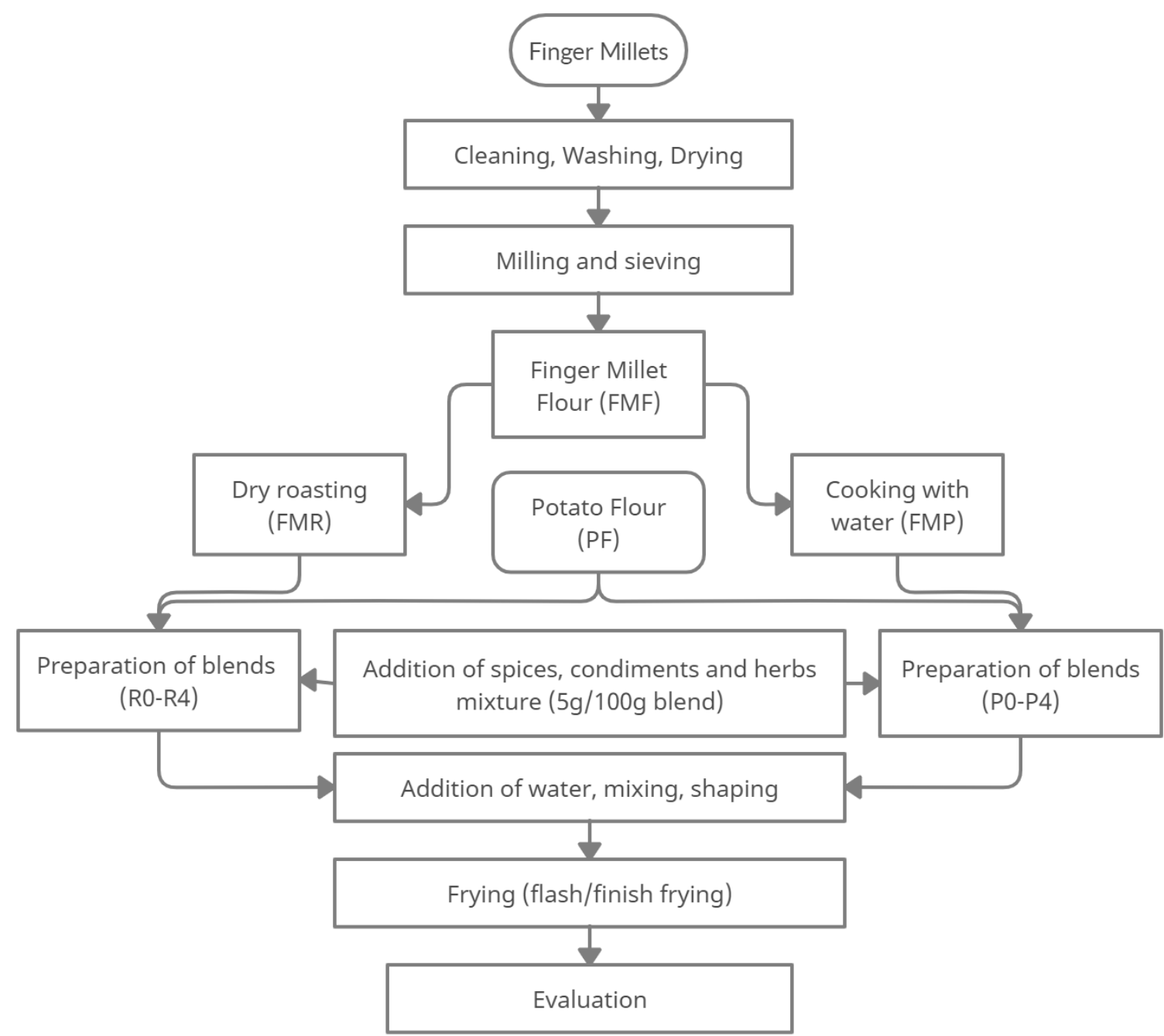

Table.1 Proximate analysis of raw materials

\begin{tabular}{|c|c|c|}
\hline Parameter & Potato flakes & Finger millet flour \\
\hline Dry matter (\%) & $93.92 \pm 3.76$ & $91.44 \pm 4.31$ \\
\hline Protein (\%) & $2.84 \pm 0.05$ & $8.10 \pm 2.01$ \\
\hline Fat (\%) & $0.11 \pm 0.01$ & $1.86 \pm 0.45$ \\
\hline Ash (\%) & $1.89 \pm 0.02$ & $2.47 \pm 0.09$ \\
\hline Fibre (\%) & $1.80 \pm 0.3$ & $3.61 \pm 0.12$ \\
\hline Carbohydrate (\%) & $87.28 \pm 4.33$ & $75.4 \pm 3.34$ \\
\hline TPC (mg GAE/100g) & $42.47 \pm 2.59$ & $320 \pm 8.54$ \\
\hline Antioxidant activity (\%) & $18.70 \pm 1.78$ & $70.0 \pm 2.99$ \\
\hline
\end{tabular}

Values are mean $\pm \mathrm{SD}, \mathrm{n}=3$ 
Table.2 Sensory evaluation of the developed gluten-free snack

\begin{tabular}{|c|c|c|c|c|c|c|}
\hline \multirow{2}{*}{ Sample } & \multicolumn{5}{|c|}{ Sensory parameters } & IA (\%) \\
\cline { 2 - 7 } & Appearance & Taste & Texture & Flavour & $\begin{array}{c}\text { Overall } \\
\text { acceptability }\end{array}$ & \\
\hline P0 & $9.0 \pm 0.23^{\mathrm{a}}$ & $9.0 \pm 0.37^{\mathrm{a}}$ & $8.0 \pm 0.34^{\mathrm{b}}$ & $8.5 \pm 0.34^{\mathrm{a}}$ & $8.82 \pm 0.32^{\mathrm{ab}}$ & $95.77 \pm 0.21^{\mathrm{ab}}$ \\
\hline P1 & $9.0 \pm 0.26^{\mathrm{a}}$ & $9.0 \pm 0.28^{\mathrm{a}}$ & $8.0 \pm 0.32^{\mathrm{b}}$ & $8.0 \pm 0.31^{\mathrm{b}}$ & $8.5 \pm 0.41^{\mathrm{ab}}$ & $94.44 \pm 0.24^{\mathrm{ab}}$ \\
\hline P2 & $9.0 \pm 0.11^{\mathrm{a}}$ & $9.0 \pm 0.31^{\mathrm{a}}$ & $9.0 \pm 0.21^{\mathrm{a}}$ & $8.5 \pm 0.28^{\mathrm{a}}$ & $8.88 \pm 0.22^{\mathrm{a}}$ & $98.66 \pm 0.11^{\mathrm{a}}$ \\
\hline P3 & $8.0 \pm 0.31^{\mathrm{b}}$ & $8.0 \pm 0.25^{\mathrm{b}}$ & $9.0 \pm 0.22^{\mathrm{a}}$ & $8.0 \pm 0.22^{\mathrm{b}}$ & $8.25 \pm 0.38^{\mathrm{b}}$ & $91.66 \pm 0.19^{\mathrm{b}}$ \\
\hline P4 & $7.0 \pm 0.19^{\mathrm{c}}$ & $7.0 \pm 0.24^{\mathrm{c}}$ & $7.0 \pm 0.32^{\mathrm{a}}$ & $7.0 \pm 0.26^{\mathrm{c}}$ & $7.0 \pm 0.31^{\mathrm{c}}$ & $77.77 \pm 0.15^{\mathrm{c}}$ \\
\hline R0 & $9.0 \pm 0.34^{\mathrm{a}}$ & $9.0 \pm 0.32^{\mathrm{a}}$ & $8.0 \pm 0.2^{\mathrm{a}}$ & $8.5 \pm 0.23^{\mathrm{a}}$ & $8.62 \pm 0.21^{\mathrm{a}}$ & $95.77 \pm 0.27^{\mathrm{a}}$ \\
\hline R1 & $8.0 \pm 0.3^{\mathrm{b}}$ & $7.0 \pm 0.32^{\mathrm{b}}$ & $7.0 \pm 0.31^{\mathrm{b}}$ & $7.5 \pm 0.26^{\mathrm{b}}$ & $7.37 \pm 0.28^{\mathrm{b}}$ & $81.88 \pm 0.22^{\mathrm{b}}$ \\
\hline R2 & $7.0 \pm 0.21^{\mathrm{c}}$ & $7.0 \pm 0.22^{\mathrm{b}}$ & $7.0 \pm 0.28^{\mathrm{b}}$ & $6.5 \pm 0.22^{\mathrm{c}}$ & $6.87 \pm 0.33^{\mathrm{c}}$ & $76.33 \pm 0.12^{\mathrm{c}}$ \\
\hline R3 & $6.0 \pm 0.22^{\mathrm{d}}$ & $6.5 \pm 0.39^{\mathrm{c}}$ & $7.0 \pm 0.22^{\mathrm{b}}$ & $6.5 \pm 0.31^{\mathrm{c}}$ & $6.5 \pm 0.25^{\mathrm{d}}$ & $72.22 \pm 0.18^{\mathrm{d}}$ \\
\hline R4 & $5.0 \pm 0.32^{\mathrm{e}}$ & $6.0 \pm 0.31^{\mathrm{d}}$ & $5.0 \pm 0.33^{\mathrm{c}}$ & $6.0 \pm 0.19^{\mathrm{d}}$ & $5.5 \pm 0.23^{\mathrm{e}}$ & $61.11 \pm 0.20^{\mathrm{e}}$ \\
\hline
\end{tabular}

Values are mean $\pm S D, n=3$; values within a row with different superscripts are significantly different $(\mathrm{p} \leq 0.05)$

Table.3 Nutritional profile of Gluten-free Snack (P2)

\begin{tabular}{|c|c|c|c|}
\hline Parameter & Values & Parameter & Values \\
\hline Dry matter (\%) & $54.8 \pm 2.77$ & Calcium $(\mathrm{mg} / 100 \mathrm{~g})$ & $151.33 \pm 6.87$ \\
\hline Protein (\%) & $4.36 \pm 0.4$ & $\begin{array}{c}\text { Magnesium } \\
(\mathrm{mg} / 100 \mathrm{~g})\end{array}$ & $57.1 \pm 3.08$ \\
\hline Fat (\%) & $15.26 \pm 3.1$ & Sodium $(\mathrm{mg} / 100 \mathrm{~g})$ & $35.6 \pm 3.27$ \\
\hline Ash (\%) & $2.36 \pm 0.04$ & Potassium $(\mathrm{mg} / 100 \mathrm{~g})$ & $355.01 \pm 7.0$ \\
\hline Fibre (\%) & $2.4 \pm 0.2$ & $\begin{array}{c}\text { Phosphorus } \\
(\mathrm{mg} / 100 \mathrm{~g})\end{array}$ & $133.25 \pm 5.72$ \\
\hline Carbohydrate (\%) & $30.42 \pm 3.99$ & Iron $(\mathrm{mg} / 100 \mathrm{~g})$ & $2.33 \pm 0.4$ \\
\hline TPC (mg GAE/100g) & $124.36 \pm 8.67$ & Zinc $(\mathrm{mg} / 100 \mathrm{~g})$ & $1.26 \pm 0.07$ \\
\hline Antioxidant activity (\%) & $41.26 \pm 2.78$ & Energy $(\mathrm{kcal} / 100 \mathrm{~g})$ & $276.46 \pm 5.86$ \\
\hline
\end{tabular}

Values are mean $\pm \mathrm{SD}, \mathrm{n}=3$

The utilization of finger millet in such foods will help to revive the consumption of this nutritious grain, cater to the need of people suffering from celiac disease and save time and drudgery involved in preparation of such snacks.

\section{References}

AOAC (2005) Association of Official Analytical Chemist, Official Methods of Analysis. 18th Edition, AOAC International, Suite 500, 481 North Frederick Avenue, Gaithersburg,
Maryland 20877-2417, USA. References - Scientific Research Publishing. (n.d.). Retrieved January 4, 2021, from https://www.scirp.org/(S(351jmbntvnsj t1 aadkposzje))/reference/ReferencesPa pers.aspx?ReferenceID $=1763751$

Chaplin, K., and Smith, A. P. (2011). Definitions and perceptions of snacking. Current Topics in Nutraceutical Research, 9(1-2), 5360.

https://doi.org/10.1016/j.appet.2006.07 .014 
Chetan, S. and M. N. G. (2007). Finger Millet Polyphenols: Characterization and thier Nutraceutical Potential. American Journal of Food Technology, 7, 582592.

Fernandes, S. S., and Salas-Mellado, M. de las M. (2017). Addition of chia seed mucilage for reduction of fat content in bread and cakes. Food Chemistry, 227, 237-244.

https://doi.org/10.1016/j.foodchem.201 7.01 .075

Glassman, K. (2017). The Importance of Snacking and Snacking Right.

Gupta and Gupta. (2012). Textbook of Field Crops Production Foodgrain Crops Volume l by Kisan Forum Pvt. Ltd. issuu. Small Millets. https://issuu.com/kisanadmin/docs/text book_of_field_crops_production_f1 $1 \mathrm{~b}$ fd6b0fb9110

He, F. J., and MacGregor, G. A. (2008). Beneficial effects of potassium on human health. Physiologia Plantarum, 133(4), 725-735. https://doi.org/10.1111/j.13993054.2007.01033.x

Herrera-Balandrano, D.., Báez-González, J.., Carvajal-Milán, E., Mendez-Zamora, G., Urías-Orona, V., Amaya-guerra, C. A., and Niño-Medina, G. (2019). Feruloylated Arabinoxylans from Nixtamalized Maize Frankfurter Sausages. Molecules, 24(2056), 1-11.

IDA. (2018). Position of The Indian Dietetic Association: Dietary Fibre and Health.

Jha, D. (2014). Biting into the Indian Snacking Market.

Kanchana, R., Fernandes, F., Barretto, K., Rodrigues, L., Pereira, S., and Karen, D. (2018). Value Added Food Products from Under-Utilized Soy Beans and Millets - From Laboratory to. March.

Kaur, B., Singh, B., Kaur, N., and Singh, D. (2018). Phytoremediation of cadmium- contaminated soil through multipurpose tree species. Agroforestry Systems, 92(2), 473-483. https://doi.org/10.1007/s10457-0170141-2

Kumar, A., Metwal, M., Kaur, S., Gupta, A. K., Puranik, S., Singh, S., Singh, M., Gupta, S., Babu, B. K., Sood, S., and Yadav, R. (2016). Nutraceutical value of finger millet [Eleusine coracana (L.) Gaertn.], and their improvement using omics approaches. Frontiers in Plant Science, $\quad 7$ (June), 1-14. https://doi.org/10.3389/fpls.2016.0093 4

Kumar, S., Sandhir, R., and Ojha, S. (2014). Evaluation of antioxidant activity and total phenol in different varieties of Lantana camara leaves. BMC Research Notes, $\quad 7(1), \quad 560$. https://doi.org/10.1186/1756-0500-7560

Malik, V. S., Willett, W. C., and Hu, F. B. (2013). Global obesity: Trends, risk factors and policy implications. Nature Reviews Endocrinology, 9(1), 13-27. https://doi.org/10.1038/nrendo.2012.19 9

Nakano, S., and Washizu, A. (2020). Aiming for better use of convenience food: An analysis based on meal production functions at home. Journal of Health, Population and Nutrition, 39(1), 1-6. https://doi.org/10.1186/s41043-0200211-3

Parameswaran, P. (2019). A Sneak Peak Into 2020 For Indian Snacking IndustryPrashant Parameswaran - $B W$ Businessworld. http://www.businessworld.in/article/ASneak-Peak-Into-2020-For-IndianSnacking-Industry/20-12-2019$180887 /$

Pettifor, J. M. (2004). Nutritional rickets: deficiency of vitamin D, calcium, or both? In The American journal of 
clinical nutrition (Vol. 80, Issue 6 Suppl). https://doi.org/10.1093/ajcn/80.6.1725s Raleng, A., Singh, A., Chavan, P., Attkan, A., and Singh, B. (2019). Standardization of deep-frying process and their effects on storage stability of pineapple pomace powder-incorporated ricebased extruded product. Journal of Food Processing and Preservation, 43(7). https://doi.org/10.1111/jfpp. 13950

Rehal, J., Kaur, G. J., Kaur, A., and Singh, A. (2017). Comparative Evaluation of Different Attributes of the Existing Extruded Snacks. Journal of Krishi Vigyan, $\quad 5(2), \quad 15$. https://doi.org/10.5958/23494433.2017.00004.6

Segundo, C., Giménez, A., Lobo, M., Iturriaga, L., and Samman, N. (2020). Formulation and attributes of glutenfree cakes of Andean corn improved with green banana flour. Food Science and Technology International, 26(2), 95-104. https://doi.org/10.1177/108201321986 0361

Sehgal, H. S., Sehgal, G. K., Thind, S. S., Kaur, A., and Rehal, J. (2010). Development of "fish mince pakora" from a cultured carp species, labeo rohita (HAM.). Journal of Food Processing and Preservation, 34(SUPPL. 1), 15-23. https://doi.org/10.1111/j.17454549.2008.00263.x

Sendhilvel, V., and Veeramani, P. (2020).
Evaluation of High Yielding and Blast Resistant Finger Millet ( Eleusine coracana ) Varieties in North Eastern Zone of Tamil Nadu. Journal of Krishi $\begin{array}{lll}\text { Vigyan, } & 8(2), & 124\end{array}$ https://doi.org/10.5958/23494433.2020.00026.4

Srinivasan, S., and Shende, K. M. (2015). A Study on the Benefits of Convenience Foods to Working Women. ATITHYA: A Journal of Hospitality, 1(1). https://doi.org/10.21863/atithya/2015.1 .1 .007

Tapia-Salazar, M., Arévalo-Rivera, I. G., Maldonado-Muñiz, M., GarciaAmezquita, L. E., Nieto-López, M. G., Ricque-Marie, D., Cruz-Suárez, L. E., and Welti-Chanes, J. (2019). The Dietary Fiber Profile, Total Polyphenol Content, Functionality of Silvetia compressa and Ecklonia arborea, and Modifications Induced by High Hydrostatic Pressure Treatments. Food and Bioprocess Technology, 12(3), 512-523. https://doi.org/10.1007/s11947-0182229-8

Vintro, A. Q. (2015). Nutrients and Timing for the Perfect Athlete's Snack. 1-4.

Yadav, D. N., Singh, K. K., and Rehal, J. (2012). Studies on fortification of wheat flour with defatted rice bran for chapati making. Journal of Food Science and Technology, 49(1). https://doi.org/10.1007/s13197-0110264-9

\section{How to cite this article:}

Jagbir Rehal, Poonam Aggarwal and Inderpreet Dhaliwal. 2021. Process Development of Gluten-Free Snack Utilising Finger Millets. Int.J.Curr.Microbiol.App.Sci. 10(02): 1231-1238. doi: https://doi.org/10.20546/ijcmas.2021.1002.144 